The Earth' crust systems of fractures of the Northern edge of the Dnieper-Donets depression on the base of remote sensing methods and their importance for oil and gas prospecting

*O. Azimov, (Scientific Centre for Aerospace Research of the Earth, IGS, NAS of Ukraine)

\title{
SUMMARY
}

Theses are devoted to investigation the tectonic structure of the Northern Edge of the DnieperDonets depression with using the lineament analysis of remote sensing data structural decoding and geological and geophysical data integral interpretation. There were picked out lineaments on the base of decoding. We grouped them to the azimuthal systems. There were compared data on the spatial structure of the lineament field and the Earth' crust fractures known by the materials of geologic and geophysical survey. As a result it was determined that the azimuths of a strike of object systems for these two classes are coincided or they are similar. So, the linear elements of the landscape reflect the disjunctive structures or neotectonic stage stresses.

Thus, the crystalline basement and sedimentary cover of the studied territory are characterized with intense dislocation by the numerous differently orientated fractures. These dislocations are of various morphogenetic kinds. These disjunctives form the system of blocks of different ranges. Carefully investigation of the fault-blocked structure features from lineament tectonic positions allows recognizing the petroleum promising sites and zones within the area.

\section{Системи розривних порушень земної кори Північного борту Дніпровсько-Донецької западини за даними дистанційних методів та їх нафтогазопошукового значення}

*О.Т. Азімов, (Науковий Центр аерокосмічних досліджень Землі Інституту геологічних наук НАН України)

РЕЗЮМЕ

Висвітлено результати вивчення тектонічної будови Північного борту Дніпровсько-Донецької западини на основі лінеаментного аналізу даних структурного дешифрування матеріалів аерокосмічних зйомок, а також комплексної геологічної інтерпретації дистанційних та геологогеофізичних даних. Виділені за матеріалами дистанційних зйомок лінеаментів згруповані нами в азимутальні системи. За результатами зіставлення даних щодо просторової організації поля лінеаментів і відомих за матеріалами геолого-геофізичних робіт розривних порушень земної кори встановлено, що азимути простягання систем об'єктів цих двох класів збігаються або дуже близькі. Отже, лінійні елементи ландшафту земної поверхні відображають диз'юнктивні структури або існуючі на новітньому етапі поля тектонічних напружень. Таким чином, розглянута територія характеризується інтенсивним дислокуванням кристалічного фундаменту та осадового чохла численними різноорієнтованими розривними порушеннями різних морфогенетичних типів. Дані диз'юнктиви утворюють систему різнопорядкових блоків. Уважне вивчення особливостей розломно-блокової будови району з позицій лінеаментної тектоніки

\section{$\mathrm{X}^{\text {th }}$ International Conference on Geoinformatics - Theoretical and Applied Aspects}


дозволило обгрунтувати в його межах ділянки і зони, перспективні для проведення подальших пошуково-розвідувальних робіт на нафту і газ.

\section{Системы разрывных нарушений земной коры Северного борта Днепровско-Донецкой впадины по данным дистанционных методов и их нефтегазопоисковое значение}

*A.T. Азимов, (Научный центр аэрокосмических исследований Земли Института геологических наук НАН Украины)

РЕЗЮМЕ

Освещены результаты изучения тектонического строения Северного борта ДнепровскоДонецкой впадины на основе линеаментного анализа данных структурного дешифрирования материалов аэрокосмических съемок, а также комплексной геологической интерпретации дистанционных и геолого-геофизических данных. Выделенные по материалам дистанционных съемок линеаменты сгруппированы нами в азимутальные системы. По результатам сопоставления данных по пространственной организации поля линеаментов и известных по материалам геолого-геофизических работ разрывных нарушений земной коры установлено, что азимуты простирания систем объектов этих двух классов совпадают или очень близки. Следовательно, линейные элементы ландшафта земной поверхности отображают дизъюнктивные структуры или существующие на новейшем этапе поля тектонических напряжений.

Таким образом, рассмотренная территория характеризуется интенсивной дислоцированностью кристаллического фундамента и осадочного чехла многочисленными разноориентированными разрывными нарушениями различных морфогенетических типов. Данные дизъюнктивы образуют систему разнопорядковых блоков. Внимательное изучение особенностей разломно-блокового строения района с позиций линеаментной тектоники позволило обосновать в его пределах участки и зоны, перспективные для проведения дальнейших поисково-разведочных работ на нефть и газ. 